\title{
Export Efficiency of Black Carbon Aerosol in Continental Outflow: Global Implications
}

\section{Citation}

Park, Rokjin J., Daniel J. Jacob, Paul I. Palmer, Antony D. Clarke, Rodney J. Weber, Mark A. Zondlo, Fred L. Eisele, et al. 2005. Export efficiency of black carbon aerosol in continental outflow: Global implications. Journal of Geophysical Research 110(D11205): 1-7.

\section{Published Version}

doi:10.1029/2004JD005432

\section{Permanent link}

http://nrs.harvard.edu/urn-3:HUL.InstRepos:3992643

\section{Terms of Use}

This article was downloaded from Harvard University's DASH repository, and is made available under the terms and conditions applicable to Other Posted Material, as set forth at http:// nrs.harvard.edu/urn-3:HUL.InstRepos:dash.current.terms-of-use\#LAA

\section{Share Your Story}

The Harvard community has made this article openly available.

Please share how this access benefits you. Submit a story.

\section{Accessibility}




\title{
Export efficiency of black carbon aerosol in continental outflow: Global implications
}

\author{
Rokjin J. Park, ${ }^{1}$ Daniel J. Jacob, ${ }^{1}$ Paul I. Palmer, ${ }^{1}$ Antony D. Clarke, ${ }^{2}$ Rodney J. Weber, ${ }^{3}$ \\ Mark A. Zondlo, ${ }^{4}$ Fred L. Eisele, ${ }^{3,4}$ Alan R. Bandy, ${ }^{5}$ Donald C. Thornton, ${ }^{5}$ \\ Glen W. Sachse, ${ }^{6}$ and Tami C. Bond ${ }^{7}$ \\ Received 11 September 2004; revised 22 February 2005; accepted 10 March 2005; published 1 June 2005.
}

[1] We use aircraft observations of Asian outflow from the NASA Transport and Chemical Evolution over the Pacific (TRACE-P) mission over the NW Pacific in March-April 2001 to estimate the export efficiency of black carbon (BC) aerosol during lifting to the free troposphere, as limited by scavenging from the wet processes (warm conveyor belts and convection) associated with this lifting. Our estimate is based on the enhancement ratio of $\mathrm{BC}$ relative to $\mathrm{CO}$ in Asian outflow observed at different altitudes and is normalized to the enhancement ratio observed in boundary layer outflow $(0-1 \mathrm{~km})$. We similarly estimate export efficiencies of sulfur oxides $\left(\mathrm{SO}_{x}=\mathrm{SO}_{2}(\mathrm{~g})+\right.$ fine $\left.\mathrm{SO}_{4}^{2-}\right)$ and total inorganic nitrate $\left(\mathrm{HNO}_{3}^{T}=\mathrm{HNO}_{3}(\mathrm{~g})+\right.$ fine $\left.\mathrm{NO}_{3}^{-}\right)$for comparison to $\mathrm{BC}$. Normalized export efficiencies for $\mathrm{BC}$ are $0.63-0.74$ at $2-4 \mathrm{~km}$ altitude and $0.27-0.38$ at $4-6 \mathrm{~km}$. Values at 2-4 km altitude are higher than for $\mathrm{SO}_{x}(0.48-0.66)$ and $\mathrm{HNO}_{3}^{T}(0.29-0.62)$, implying that $\mathrm{BC}$ is scavenged in wet updrafts but not as efficiently as sulfate or nitrate. Simulation of the TRACE-P period with a global three-dimensional model (GEOS-CHEM) indicates that a model timescale of $1 \pm 1$ days for conversion of fresh hydrophobic to hydrophilic BC provides a successful fit to the export efficiencies observed in TRACE-P. The resulting mean atmospheric lifetime of $\mathrm{BC}$ is $5.8 \pm 1.8$ days, the global burden is $0.11 \pm 0.03 \mathrm{Tg} \mathrm{C}$, and the decrease in Arctic snow albedo due to $\mathrm{BC}$ deposition is $3.1 \pm 2.5 \%$.

Citation: Park, R. J., et al. (2005), Export efficiency of black carbon aerosol in continental outflow: Global implications, J. Geophys. Res., 110, D11205, doi:10.1029/2004JD005432.

\section{Introduction}

[2] Black carbon (BC), operationally defined as the lightabsorbing fraction of carbonaceous aerosols, has complex climatic implications involving atmospheric heating and surface cooling [National Research Council, 2005]. It consists of elemental carbon as well as heavy nonpolar organic compounds [Marley et al., 2001]. It is emitted to the atmosphere by incomplete combustion [Cooke et al., 1999]. The freshly emitted BC is mostly hydrophobic and eventually becomes hydrophilic by oxidation or coating

\footnotetext{
${ }^{1}$ Division of Engineering and Applied Sciences and Department of Earth and Planetary Sciences, Harvard University, Cambridge, Massachusetts, USA.

${ }^{2}$ School of Ocean and Earth Science and Technology, University of Hawaii at Manoa, Honululu, Hawaii, USA.

${ }^{3}$ School of Earth and Atmospheric Sciences, Georgia Institute of Technology, Atlanta, Georgia, USA.

${ }^{4}$ National Center for Atmospheric Research, Boulder, Colorado, USA.

${ }^{5}$ Department of Chemistry, Drexel University, Philadelphia, Pennsylvania, USA.

${ }^{6}$ NASA Langley Research Center, Hampton, Virginia, USA.

${ }^{7}$ Department of Civil and Environmental Engineering, University of Illinois at Urbana-Champaign, Urbana, Illinois, USA.

Copyright 2005 by the American Geophysical Union. 0148-0227/05/2004JD005432\$09.00
}

with sulfate and organics [Langner et al., 1992; Parungo et al., 1994; Liousse et al., 1993, 1996]. This conversion is critical for the incorporation of BC in cloud droplets and subsequent removal by rain out. Most global models assume that it takes place on a timescale of 1 day [Cooke and Wilson, 1996; Cooke et al., 1999; Chin et al., 2002; Chung and Seinfeld, 2002; Park et al., 2003]. Cooke and Wilson [1996] first used this timescale on the basis of their comparisons of simulated versus observed BC concentrations in surface air at Amsterdam Island in the Indian Ocean. A global model simulation of aerosol microphysics by Jacobson [2001a] indicates that $50 \%$ of BC mass acquires a hydrophilic coating $(>20 \%)$ within 1 day of emission. The scavenging efficiency of $\mathrm{BC}$ has major consequences for climate forcing since outflow from source regions to the free troposphere mainly takes place by wet processes including warm conveyor belts (WCBs) and convection [Thompson et al., 1994; Stohl, 2001; Cooper et al., 2002; Liu et al., 2003]. Once in the free troposphere, $\mathrm{BC}$ can be transported on a global scale because precipitation is infrequent.

[3] We present here an assessment of the export efficiency of $\mathrm{BC}$ in Asian outflow using aircraft observations over the NW Pacific from the NASA Transport and Chemical Evolution over the Pacific (TRACE-P) mission in 
March-April 2001 [Jacob et al., 2003]. The TRACE-P observations provided an extensive characterization of Asian outflow to the Pacific in early spring when this outflow is particularly strong [Liu et al., 2003]. Most of the outflow was driven by midlatitude cyclones, with WCB lifting ahead of the associated cold fronts and boundary layer outflow behind the fronts [Liu et al., 2003]. East Asia is a major source region for $\mathrm{BC}$, contributing $\sim 30 \%$ to global anthropogenic $\mathrm{BC}$ emissions, mostly from industry, residential coal burning, and biofuel use [Bond et al., 2004]. We compare the observed vertical profiles of $\mathrm{BC}$ to those of other soluble and insoluble species measured aboard the aircraft to provide constraints on $\mathrm{BC}$ solubility. We then apply the GEOS-CHEM global chemical transport model [Bey et al., 2001] to the TRACE-P observations in order to test the $\mathrm{BC}$ scavenging parameterization commonly used in global models and to examine the consequences for the global burden of $\mathrm{BC}$ and the deposition of $\mathrm{BC}$ to the Arctic. The latter could make an important contribution to climate warming by decreasing snow albedo [Warren and Wiscombe, 1985; Clarke and Noone, 1985; Hansen and Sato, 2001; Hansen and Nazarenko, 2004].

\section{Observations}

[4] The TRACE-P aircraft mission was conducted offshore of the Asian Pacific Rim during March-April 2001 and focused on chemical characterization of Asian outflow. It used two aircraft, a DC-8 (12-km ceiling) and a P-3B (7-km ceiling), operating out of Hong Kong and Japan. Measurements aboard both aircraft included $\mathrm{BC}$, aerosol sulfate $\left(\mathrm{SO}_{4}^{2-}\right)$, aerosol nitrate $\left(\mathrm{NO}_{3}^{-}\right), \mathrm{SO}_{2}$, gas phase nitric acid $\left(\mathrm{HNO}_{3}\right)$, and $\mathrm{CO}$, among other species. $\mathrm{BC}$ was measured by optical absorption at $565-\mathrm{nm}$ wavelength using a particle/soot absorption photometer (PSAP) (Radiance Research, Seattle, Washington) with correction for artifact absorption from aerosol scattering [Bond et al., 1999]. A mass absorption efficiency of $7 \mathrm{~m}^{2} \mathrm{~g}^{-1}$ [Clarke et al., 2004] was assumed to convert to mass concentration. This conversion factor was derived from collocated measurements of PSAP absorption and black carbon mass concentrations from the Asian Pacific Regional Aerosol Characterization Experiment (ACE-Asia) aircraft mission conducted over the NW Pacific concurrently with TRACE-P [Huebert et al., 2003]. Intercomparison flight legs during TRACE-P indicated that the aerosol absorption measurements on the DC8 were systematically higher than on the P-3B and implied unrealistically low aerosol single scattering albedos above $3 \mathrm{~km}$ altitude [Moore et al., 2004]. We only use the P-3B data in our analysis.

[5] Fine aerosol concentrations of $\mathrm{SO}_{4}^{2-}, \mathrm{NO}_{3}^{-}$, and $\mathrm{Na}^{+}$ were measured aboard the $\mathrm{P}-3 \mathrm{~B}$ using a particle-into-liquid sampler (PILS) with an upper size cutoff of $1.3 \mu \mathrm{m}$ [Weber et al., 2003]. We use the $\mathrm{Na}^{+}$data to remove the sea salt contribution to $\mathrm{SO}_{4}^{2-}$ on the basis of the $\mathrm{Na}^{+} / \mathrm{SO}_{4}^{2-}$ ratio in seawater [Keene et al., 1986]. $\mathrm{SO}_{2}$ and $\mathrm{HNO}_{3}$ measurements aboard the $\mathrm{P}-3 \mathrm{~B}$ were made using atmospheric pressure ionization mass spectrometry [Tu et al., 2003] and chemical ionization mass spectrometry (CIMS) [Zondlo et al., 2003], respectively. We refer to the sum of $\mathrm{SO}_{2}$ and fine non-sea-salt (nss) $\mathrm{SO}_{4}^{2-}$ as total sulfur oxides $\left(\mathrm{SO}_{x}\right)$, and we refer to the sum of $\mathrm{HNO}_{3}$ and fine $\mathrm{NO}_{3}^{-}$as total inorganic nitrate $\left(\mathrm{HNO}_{3}^{T}\right)$. Gas phase sulfuric acid $\left(\mathrm{H}_{2} \mathrm{SO}_{4}\right)$ was also measured on the P-3B by CIMS [Mauldin et al., 2003] but represents $<1 \%$ of $\mathrm{SO}_{x}$ and was not included in our analysis. Because of the upper size cutoff of PILS the P$3 \mathrm{~B} \mathrm{SO}_{x}$ and $\mathrm{HNO}_{3}^{T}$ data did not include a substantial fraction of aerosol sulfate and nitrate associated with coarse soil dust and sea-salt aerosols as indicated by bulk aerosol filter measurements aboard the DC-8 [Jordan et al., 2003]. Measurements of $\mathrm{CO}$ were made by tunable diode laser spectrometry (differential absorption CO measurement instrument) [Sachse et al., 1987]. All data used here are averages along the flight tracks on the GEOS-CHEM $2^{\circ} \times$ $2.5^{\circ}$ horizontal grid.

\section{Export Efficiencies Constrained by Observations}

[6] Koike et al. [2003] previously used the TRACE-P data to estimate export efficiencies of $\mathrm{SO}_{x}$ and total reactive nitrogen oxides $\left(\mathrm{NO}_{y}\right)$ from east Asia. Similar to $\mathrm{BC}, \mathrm{SO}_{x}$ and $\mathrm{NO}_{y}$ originate mainly from combustion and are removed from the atmosphere by deposition. By reference to $\mathrm{CO}$ as an inert combustion tracer, Koike et al. [2003] computed the altitude-dependent export efficiencies in east Asian outflow as the ratios of the species enhancements above their background to the corresponding $\mathrm{CO}$ enhancements, normalized by the emission ratio for the source region. We can apply this approach to estimate the export efficiency $f_{X}(\mathrm{z})$ of any combustion-derived species $X$ at altitude $z$ :

$$
f_{X}(z)=\frac{1}{R_{X}}\left(\frac{\Delta[X]}{\Delta[\mathrm{CO}]}\right)(z),
$$

where $R_{X}$ is the emission ratio of $X$ to $\mathrm{CO}$ and $\Delta$ denotes the concentration enhancements relative to background.

[7] We focus on TRACE-P outflow observations north of $30^{\circ} \mathrm{N}$ in our application of equation (1), as these originated from a well-defined east Asian source region including China, Korea, and Japan [Liu et al., 2003]. Outflow south of $30^{\circ} \mathrm{N}$ often had a large influence from biomass burning in Southeast Asia with different emission ratios. For comparison of $\mathrm{SO}_{x}$ and $\mathrm{BC}$ export efficiencies we further restrict our attention to data west of $140^{\circ} \mathrm{E}$ because of $\mathrm{SO}_{2}$ emissions from an active volcano on Miyakejima Island $\left(34^{\circ} \mathrm{N}, 139^{\circ} \mathrm{E}\right)$ [Koike et al., 2003]. The TRACE-P outflow observations were typically taken $1-3$ days downwind from the points of emission in the east Asian source region [Fuelberg et al., 2003; Russo et al., 2003].

[8] Emission ratio estimates for east Asia (defined here as China, Korea, and Japan) are needed for application of equation (1). We use an east Asian $\mathrm{BC}$ emission for the 3month TRACE-P period of $0.45 \mathrm{Tg} \mathrm{C}$, including $0.42 \mathrm{Tg} \mathrm{C}$ from anthropogenic sources [Bond et al., 2004] and $0.03 \mathrm{Tg}$ $\mathrm{C}$ from biomass burning. The small biomass burning contribution was estimated by applying $\mathrm{BC}$ emission factors from Andreae and Merlet [2001] to dry mass burned data with monthly resolution averaged over 1997-2000 from Duncan et al. [2003]. We use a CO emission estimate of $19.2 \mathrm{Tg} \mathrm{C}$ for the same region and period as obtained by Palmer et al. [2003] by fitting the TRACE-P CO observations with an inverse model. The resulting $\mathrm{BC} / \mathrm{CO}$ emission 


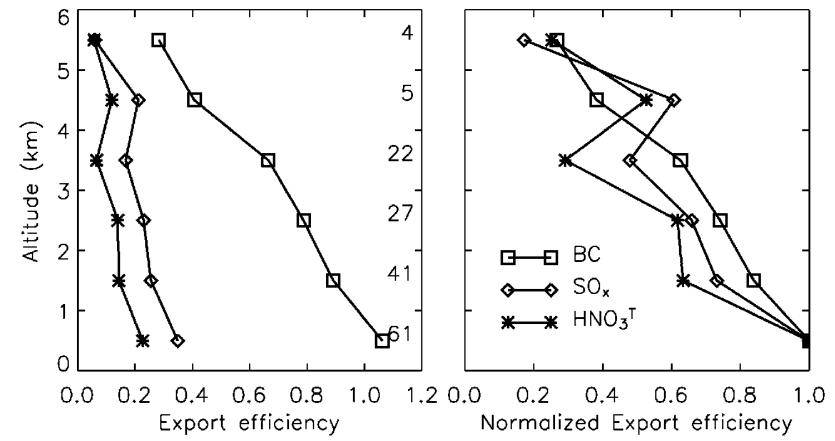

Figure 1. Mean vertical profiles of (left) export efficiency and (right) normalized export efficiency in Asian outflow for black carbon (BC) (squares), $\mathrm{SO}_{x}$ defined as the sum of $\mathrm{SO}_{2}$ and fine non-sea-salt sulfate aerosol (diamonds), and $\mathrm{HNO}_{3}{ }^{T}$ defined as the sum of $\mathrm{HNO}_{3}$ and fine inorganic nitrate aerosol (asterisks). The export efficiencies are derived by application of equations (1) and (2) to the Transport and Chemical Evolution over the Pacific (TRACE-P) P-3B measurements over the NW Pacific $\left(30^{\circ}-41^{\circ} \mathrm{N}, 124^{\circ}-140^{\circ} \mathrm{E}\right)$, The number of measurements used to calculate export efficiencies at each altitude is also shown.

ratio for east Asia is 0.023 (g C/g C). We also obtain regional $\mathrm{SO}_{2}$ and $\mathrm{NO}_{x}$ emission ratios relative to $\mathrm{CO}$ of 0.064 and $0.060 \mathrm{~mol} \mathrm{~mol}^{-1}$, respectively, using east Asian $\mathrm{SO}_{2}$ and $\mathrm{NO}_{x}$ emissions for the 3-month TRACE-P period of $3.26 \mathrm{Tg} \mathrm{S}$ and $1.34 \mathrm{Tg} \mathrm{N}$ [Park et al., 2004]. Our $\mathrm{SO}_{2}$ and $\mathrm{NO}_{x}$ emission ratios relative to $\mathrm{CO}$ are slightly lower than the values $(0.069$ and 0.070$)$ used by Koike et al. [2003] on the basis of the Streets et al. [2003] regional inventory for the TRACE-P period. The CO source for the east Asian region in that inventory is $30 \%$ lower than the inverse model results of Palmer et al. [2003].

[9] BC emission estimates for east Asia are highly uncertain [Carmichael et al., 2003], and this uncertainty propagates into our calculation of the export efficiency. We also compute a normalized export efficiency $f_{X, \text { norm }}(z)$ as the ratio of the altitude-dependent export efficiency to its surface value:

$$
f_{X, \text { norm }}(z)=\frac{f_{X}(z)}{f_{X}(0)}
$$

This normalized export efficiency should overestimate the actual export efficiency because it does not account for scavenging in boundary layer outflow as measured by $f_{X}(0)$. However, it has the advantage of being independent of $R_{X}$ as long as one assumes that the same value of $R_{X}$ applies to outflow at all altitudes.

[10] Application of equations (1) and (2) requires estimates of background concentrations in air upwind from the source region [Mauzerall et al., 1998], especially for CO which has a substantial background because of its long atmospheric lifetime. Koike et al. [2003] estimated background $\mathrm{CO}$ for individual aircraft measurements in TRACE-P by a complicated approach involving the CO$\mathrm{CO}_{2}$ relationship. We use here the inverse model analysis of
Palmer et al. [2003] that fitted GEOS-CHEM sources of CO to match the TRACE-P CO observations and decomposed CO concentrations along the TRACE-P flight tracks in terms of contributions from different source regions and source types. We define the local CO background along the aircraft flight tracks as the sum of contributions from the oxidation of methane, oxidation of biogenic nonmethane volatile organic compounds, and anthropogenic sources outside of east Asia. We then add to that value a 16-ppbv enhancement from circumpolar transport of $\mathrm{CO}$ emitted by east Asian anthropogenic sources, as determined from the average concentration contributed by these sources in the lower troposphere $(0-5 \mathrm{~km})$ over the Middle East $\left(75^{\circ} \mathrm{E}\right)$ upwind of east Asia. Our resulting means and standard deviations of background CO concentrations for the TRACE-P data set are $129 \pm 11$ and $116 \pm 10 \mathrm{ppbv}$ in the boundary layer $(0-2 \mathrm{~km})$ and the free troposphere $(2-6 \mathrm{~km})$, respectively.

[11] We also assume background values of $50 \mathrm{ppt}$ for BC and 100 ppt for $\mathrm{SO}_{x}$ and $\mathrm{HNO}_{3}^{T}$ as the low tails of the frequency distributions of concentrations in the TRACE-P data. These species have short lifetimes, and hence the specification of background is not critical.

[12] Figure 1 (left) shows the mean vertical profiles of export efficiency, and Figure 1 (right) shows normalized export efficiency of $\mathrm{BC}$ for the ensemble of observations over the $\left(30-41^{\circ} \mathrm{N}, 124^{\circ}-140^{\circ} \mathrm{E}\right)$ TRACE-P domain. The profiles were constructed by taking the values of $\triangle \mathrm{BC}$ and $\Delta \mathrm{CO}$ for individual observations of $\Delta \mathrm{CO}>10 \mathrm{ppbv}$, averaging them over $1-\mathrm{km}$ vertical intervals, and then using these average quantities for input to equation (1). The $\Delta \mathrm{CO}$ threshold of $10 \mathrm{ppbv}$ is intended to select outflow air masses. Koike et al. [2003] used a higher threshold, $\Delta \mathrm{CO}$ $>30 \mathrm{ppbv}$, but we find that this does not affect the results significantly and the lower threshold yields more robust statistics. Our analysis thus includes 102 data points at $0-$ $2 \mathrm{~km}$ altitude, 49 at $2-4 \mathrm{~km}$, and 9 above $4 \mathrm{~km}$.

[13] We estimate export efficiencies for BC of 0.89-1.06 in the boundary layer $(0-2 \mathrm{~km}), 0.67-0.79$ at $2-4 \mathrm{~km}$, and $0.28-0.41$ at $4-6 \mathrm{~km}$. The decreasing export efficiencies with altitude indicate wet scavenging of $\mathrm{BC}$ during vertical transport. The value of 1.06 at $0-1 \mathrm{~km}$ is not significantly different from 1 , considering the uncertainty in the approach, in particular the low bias in the $\mathrm{BC}$ emission inventory as discussed in section 4 .

[14] We also show in Figure 1 the export efficiencies of $\mathrm{SO}_{x}$ and $\mathrm{HNO}_{3}^{T}$, calculated by applying the same method and with reference to emissions of $\mathrm{SO}_{2}$ and $\mathrm{NO}_{x}$. The export efficiency of $\mathrm{HNO}_{3}^{T}$ represents the fraction of emitted $\mathrm{NO}_{x}$ that is exported as $\mathrm{HNO}_{3}^{T}$. Values for $\mathrm{SO}_{x}$ and $\mathrm{HNO}_{3}^{T}$ are $0.25-0.35$ and $0.14-0.23$ at $0-2 \mathrm{~km}, 0.17-0.23$ and $0.07-$ 0.14 at $2-4 \mathrm{~km}$, and $0.06-0.21$ and $0.06-0.12$ at $4-6 \mathrm{~km}$, respectively. Koike et al. [2003] previously reported export efficiencies for $\mathrm{SO}_{x}$ and $\mathrm{NO}_{y}$ of $0.20-0.45$ in the boundary layer $(0-2 \mathrm{~km})$ and 0.15 in the free troposphere $(2-7 \mathrm{~km})$. Our values for $\mathrm{SO}_{x}$ are consistent; our values for $\mathrm{HNO}_{3}^{T}$ are lower than for $\mathrm{NO}_{y}$, as would be expected because of the large contribution of insoluble peroxyacetylnitrate to the exported $\mathrm{NO}_{y}$. Molar ratios of $\mathrm{HNO}_{3}^{T} / \mathrm{NO}_{y}$ and $\mathrm{nsSSO}_{4}^{2-}$ / $\mathrm{SO}_{x}$ in east Asian anthropogenic plumes at $0-1 \mathrm{~km}$ altitude were 0.5 and 0.6 , respectively [Koike et al., 2003].

[15] The observed BC export efficiencies are much higher than those of $\mathrm{SO}_{x}$ and $\mathrm{HNO}_{3}^{T}$ in the boundary layer outflow. 
This could be explained by inefficient removal of fresh BC in the source region. In addition, boundary layer outflow is a dry process, and $\mathrm{BC}$ (unlike the gas phase species $\mathrm{SO}_{2}$ and $\mathrm{HNO}_{3}$ ) is not removed efficiently by dry deposition. The uncertainty in $\mathrm{BC}$ emission is a complicating factor, as regional modeling by Carmichael et al. [2003] of the $\mathrm{BC}$ observations in TRACE-P implies that east Asian BC sources in the Bond et al. [2004] inventory are underestimated. We address that issue further in section 4 .

[16] The normalized export efficiencies for $\mathrm{BC}, \mathrm{SO}_{x}$, and $\mathrm{HNO}_{3}^{T}$ in Figure 1 (right) show a decrease with altitude. In the lower free troposphere $(2-4 \mathrm{~km})$, which was a prevailing WCB outflow altitude during TRACE-P [Carmichael et al., 2003; Liu et al., 2003], the BC normalized export efficiency $(0.63-0.74)$ is higher than that of $\mathrm{SO}_{x}(0.48-$ $0.66)$ or $\mathrm{HNO}_{3}^{T}(0.29-0.62)$. The higher normalized export efficiency for $\mathrm{BC}$ relative to $\mathrm{SO}_{x}$ and $\mathrm{HNO}_{3}^{T}$ implies some resistance to scavenging and thus some hydrophobic character. At $5-6 \mathrm{~km}$, there is no significant difference in the normalized export efficiencies of $\mathrm{HNO}_{3}^{T}, \mathrm{SO}_{x}$, and $\mathrm{BC}$ $(0.17-0.27)$. This could reflect a more thorough processing of the outflow by precipitation, but there are only nine data points contributing to the calculation of export efficiencies above $4 \mathrm{~km}$, and thus the estimates are uncertain.

\section{Model Simulation: Implications for Black Carbon Scavenging}

[17] We use the GEOS-CHEM three-dimensional model of aerosol-oxidant chemistry [Bey et al., 2001; Park et al., 2003, 2004] to examine the constraints from the TRACE-P observations on the standard representation of BC scavenging used in global models. The GEOS-CHEM model (version 6.02, available at http://www-as.harvard.edu/chemistry/trop/geos) uses assimilated meteorological data for the TRACE-P period from the NASA Goddard Earth Observing System (GEOS-3) including winds, convective mass fluxes, mixing depths, temperature, precipitation, and surface properties. The data have 6-hour temporal resolution (3-hour for surface variables and mixing depths), $1^{\circ} \times 1^{\circ}$ horizontal resolution, and 48 sigma vertical layers. We degrade the horizontal resolution to $2^{\circ} \times 2.5^{\circ}$ for input to GEOSCHEM.

[18] The simulation of BC aerosols in GEOS-CHEM is as described by Park et al. [2003] with updated emissions as described below. The simulation of $\mathrm{SO}_{x}$ and $\mathrm{HNO}_{3}^{T}$ species is as described by Park et al. [2004] with nitrate aerosol formation driven by $\mathrm{H}_{2} \mathrm{SO}_{4}-\mathrm{HNO}_{3}-\mathrm{NH}_{3}-\mathrm{H}_{2} \mathrm{O}$ thermodynamics. Wet deposition follows the scheme of Liu et al. [2001], including contributions from scavenging in convective updrafts, rain out from convective anvils, rain out and washout from large-scale precipitation, and species-dependent release of gases upon cloud freezing [Mari et al., 2000]. The scheme was originally tested by simulation of aerosol radionuclides [Liu et al., 2001] and also yields a good simulation of soluble species concentrations in the United States [Park et al., 2003, 2004] and in North American outflow [ $\mathrm{Li}$ et al., 2004]. Dry deposition is simulated with a standard resistance-in-series model dependent on local surface type and meteorological conditions, as described by Wang et al. [1998]; it is important for gaseous $\mathrm{SO}_{2}$ and $\mathrm{HNO}_{3}$ but not for fine aerosols.
[19] The model simulation of BC treats hydrophobic and hydrophilic BC as two separate transported species. Following the standard parameterization used in global models, we assume that all $\mathrm{BC}$ is emitted as hydrophobic and becomes hydrophilic with an $e$-folding time $\tau$. Global models of BC commonly assume $\tau=1$ day, as mentioned previously (in section 1). We examine here the constraints on $\tau$ from the TRACE-P observations. Wet deposition is applied only to hydrophilic BC. Hydrophobic BC can also be scavenged by collision with cloud droplets and falling raindrops, but the effect on aerosol mass is small [Jacobson, 2003].

[20] We use global anthropogenic (fuel) emissions of BC

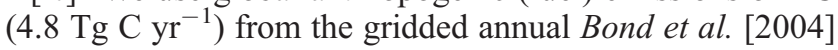
inventory for 1996. The BC emissions from fossil fuel and biofuel in east Asia are 1.2 and $0.43 \mathrm{Tg} \mathrm{C} \mathrm{yr}^{-1}$, respectively. Biomass burning emissions are specified from a gridded climatological inventory with monthly resolution [Duncan et al., 2003] and using BC emission factors from Andreae and Merlet [2001]. The resulting global annual BC emission

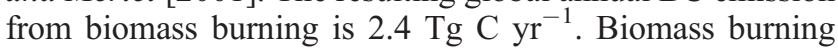
emissions in east Asia during TRACE-P are 0.03 Tg C, much lower than fuel emissions.

[21] Model simulations are conducted from August 2000 to December 2001. The first 5 months are used for initialization. We focus on results for 2001. For comparison with the TRACE-P observations we sample the 3-hour average model results along the TRACE-P flight tracks and for the flight periods.

[22] Figure 2 compares mean observed and simulated vertical concentration profiles of $\mathrm{SO}_{x}, \mathrm{HNO}_{3}^{T}$, and fine $\mathrm{NO}_{3}^{-}$for the ensemble of TRACE-P flights over the east Asian outflow domain $\left(30^{\circ}-41^{\circ} \mathrm{N}, 124^{\circ}-140^{\circ} \mathrm{E}\right)$. The simulated and observed $\mathrm{SO}_{x}$ concentrations decrease rapidly with altitude, and there is no significant model bias. The simulated $\mathrm{HNO}_{3}^{T}$ concentration is a factor of 1.8 higher than observed. An explanation is that the model does not account for the uptake of $\mathrm{HNO}_{3}$ on coarse soil dust and sea-salt aerosols [Grassian, 2001] which would be excluded from the $\mathrm{HNO}_{3}^{T}$ measurement. Bulk aerosol measurements from the DC- 8 aircraft during TRACE-P indicated that $50 \%$ of total inorganic nitrate and $20 \%$ of total sulfur oxides, on average, were incorporated in coarse soil dust aerosols in dust-impacted Asian outflow [Jordan et al., 2003]. Recent measurements in Japan during the Asian dust season [Ooki and Uematsu, 2005] indicated that $50 \%$ of $\mathrm{HNO}_{3}$ reacted with soil dust aerosols, on average, but only $10 \%$ of $\mathrm{SO}_{2}$ reacted. Aerosol nitrate in the model is mainly fine $\mathrm{NH}_{4} \mathrm{NO}_{3}$ and reproduces well the fine $\mathrm{NO}_{3}^{-}$observations aboard the $\mathrm{P}-3 \mathrm{~B}$, as shown in Figure 2. Overall, the good simulation of $\mathrm{SO}_{x}$ and fine $\mathrm{NO}_{3}^{-}$indicates a successful simulation of Asian outflow and associated scavenging for the TRACE-P period.

[23] We also compare in Figure 2 the mean observed and simulated vertical concentration profiles of $\mathrm{BC}$, using $\tau=1$ day in the model to describe $\mathrm{BC}$ scavenging. The observed $\mathrm{BC}$ concentration is, on average, $60 \%$ higher than the simulation, which could reflect either insufficient emission or excessive scavenging. We test for the latter in Figure 3 by comparing simulated and observed values of the normalized export efficiencies for BC. For this comparison we use TRACE-P outflow data extending east to $150^{\circ} \mathrm{E}\left(30^{\circ}-\right.$ 


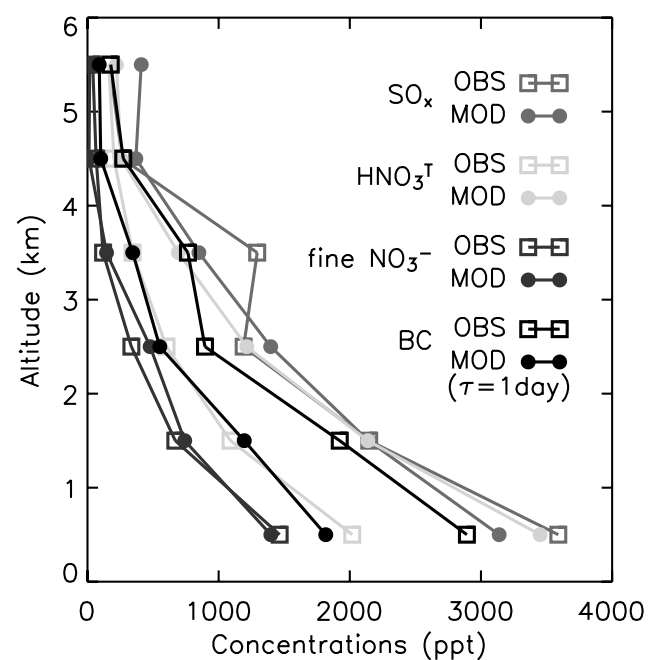

Figure 2. Mean vertical profiles of simulated (solid circles) versus observed (squares) concentrations of $\mathrm{SO}_{x}$ (red), $\mathrm{HNO}_{3}{ }^{T}$ (green), fine $\mathrm{NO}_{3}{ }^{-}$(blue), and $\mathrm{BC}$ (black) for the ensemble of TRACE-P P-3B observations over the NW Pacific $\left(30^{\circ}-41^{\circ} \mathrm{N}, 124^{\circ}-140^{\circ} \mathrm{E}\right)$. The model results were sampled along the aircraft flight tracks. The data were binned in 1-km vertical intervals and were then averaged to construct the profiles. See color version of this figure at back of this issue.

$\left.41^{\circ} \mathrm{N}, 124^{\circ}-150^{\circ} \mathrm{E}\right)$ to have better statistics since comparison to $\mathrm{SO}_{x}$ export efficiency is not an issue. The change in domain results in a slight increase $(\sim 5 \%)$ in the computed $\mathrm{BC}$ export efficiency relative to that in Figure 1. The normalized export efficiencies in the model are computed in the same way as in the observations and for model values of $\tau$ ranging from 0 to 5 days to test the sensitivity to $\tau$. From Figure 3 we see that $\tau=1$ day (as assumed in our standard simulation) reproduces the observed vertical profile of the normalized export efficiency, implying that scavenging bias is not responsible for the model underestimate of BC concentrations in Figure 2. Emissions in the Bond et al. [2004] inventory are likely too low, as suggested also in previous analyses of the TRACE-P data [Carmichael et al., 2003; Clarke et al., 2004]. Test simulations indicate that increasing east Asian emissions by $60 \%$ relative to the Bond et al. [2004] inventory would correct the discrepancy in the GEOS-CHEM simulation. Increasing $\tau$ up to 5 days would not.

\section{Implications for the Global BC Budget and for Deposition to the Arctic}

[24] Comparison of model results to TRACE-P observations in Figure 3 shows that our best estimate of the timescale $\tau$ for conversion of hydrophobic to hydrophilic $\mathrm{BC}$ in global models is 1 day, with a likely range of $0-$ 2 days (i.e., $\tau=1 \pm 1$ days). We examine the implications for the simulation of the global burden of $\mathrm{BC}$ and the deposition flux to the Arctic north of $70^{\circ} \mathrm{N}$. Figure 4 shows the simulated $\mathrm{BC}$ burden, annual wet deposition flux in the Arctic, and corresponding decrease in Arctic snow albedo as a function of $\tau$. The global burden of $\mathrm{BC}$ increases by a factor of 3 as $\tau$ increases from 0 to 5 days. A value for $\tau$ of $1 \pm 1$ days combined with the Bond et al. [2004] global

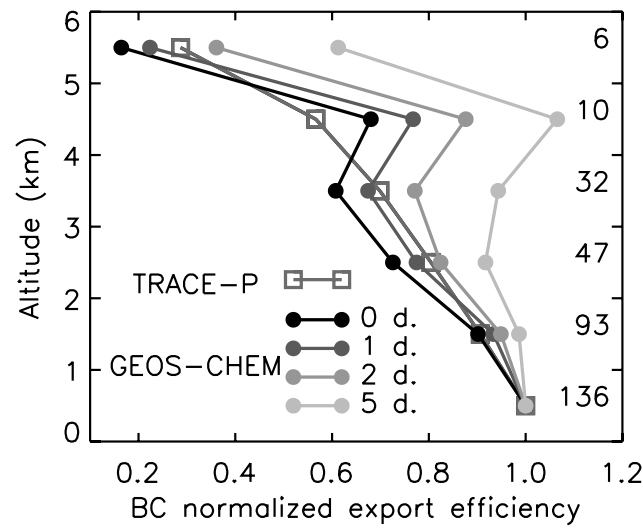

Figure 3. Comparison of simulated (solid circles) versus observed (squares) normalized export efficiencies of $\mathrm{BC}$ for the ensemble of observations and for model values of $\tau$ ranging from 0 to 5 days as indicated by the inset. The normalized export efficiencies are calculated using equation (2) for the ensemble of TRACE-P P-3B flights over the domain $\left(30^{\circ}-41^{\circ} \mathrm{N}, 124^{\circ}-150^{\circ} \mathrm{E}\right)$. The number of measurements used to calculate export efficiencies at each altitude is also shown. See color version of this figure at back of this issue.

inventory yields a global $\mathrm{BC}$ burden of $0.11 \pm 0.03 \mathrm{Tg} \mathrm{C}$, lower than values of $0.17-0.32 \mathrm{Tg} \mathrm{C}$ found in previous global model studies [Cooke and Wilson, 1996; Jacobson, 2001b; Chuang et al., 2002; Chung and Seinfeld, 2002; Chin et al., 2002; Wang, 2004]. This reflects our lower BC

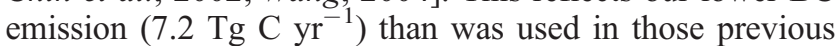
studies $\left(12-18.7 \mathrm{Tg} \mathrm{C} \mathrm{yr}^{-1}\right)$. An Intergovernmental Panel on Climate Change [2001] intercomparison of global model simulations with imposed $\mathrm{BC}$ emission of $12.4 \mathrm{Tg} \mathrm{C} \mathrm{yr}^{-1}$ found a mean high bias of a factor of 2.3 compared to observations averaged over all sites, although with considerable scatter. The Bond et al. [2004] inventory would partly correct this global mean bias, although as we have seen, it is too low in east Asia. With $\tau=1 \pm 1$ days we compute in the

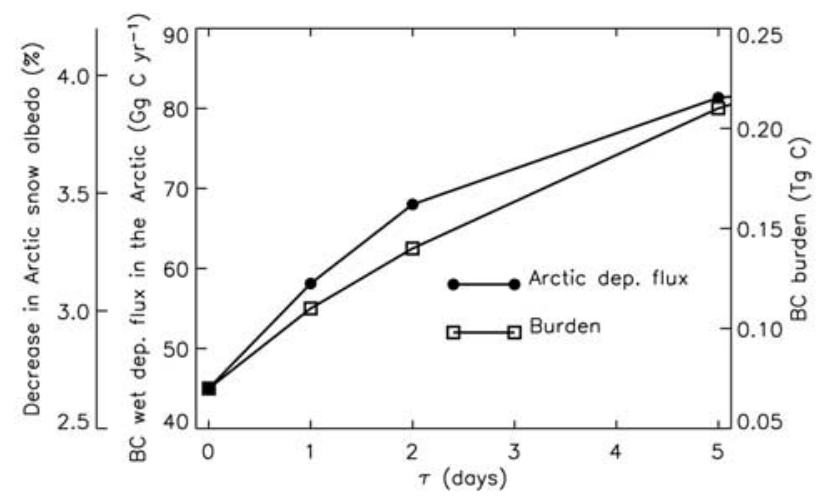

Figure 4. Simulated global BC burden (squares) and wet deposition flux of $\mathrm{BC}$ to the Arctic north of $70^{\circ} \mathrm{N}$ (solid circles) as a function of the time constant $\tau$ for conversion from hydrophobic to hydrophilic BC. Values are annual means for 2001. The scale on the far left indicates the decrease in Arctic snow albedo implied by the BC wet deposition flux. Our best estimate for $\tau$ is $1 \pm 1$ days. 
model a mean atmospheric lifetime for $\mathrm{BC}$ of $5.8 \pm 1.8$ days, which is within the range of 4.0-7.9 days found in the above-cited studies.

[25] Our simulated annual BC deposition flux north of $70^{\circ} \mathrm{N}$ computed with $\tau=1 \pm 1$ days is $58 \pm 12 \mathrm{Gg} \mathrm{C} \mathrm{yr}^{-1}$. Our simulated BC scavenging ratio in the Arctic, defined as the mixing ratio of $\mathrm{BC}$ in precipitation divided by that in surface air [Clarke and Noone, 1985], is $138 \pm 15\left(\left[\mathrm{~g} \mathrm{BC} \mathrm{g}^{-1}\right.\right.$ meltwater $] /\left[\mathrm{g} \mathrm{BC} \mathrm{g}^{-1}\right.$ air $]$ ), consistent with the observed range of 30-190 [Clarke and Noone, 1985; Noone and Clarke, 1988]. The GEOS-3 data for 2001 indicate an annual precipitation north of $70^{\circ} \mathrm{N}$ of $262 \mathrm{~mm} \mathrm{yr}^{-1}$. With $\tau=1 \pm$ 1 days we obtain a simulated $\mathrm{BC}$ concentration in Arctic snow of $13 \pm 2.6$ ppbw (parts per billion by weight, equivalent to $\mu \mathrm{g} \mathrm{L}^{-1}$ meltwater), consistent with the 450 ppbw range found in observations [Clarke and Noone, 1985; Grenfell et al., 2002] and with the value of 11 ppbw found in a previous global model calculation [Jacobson, 2004]. Previously calculated decreases in visible snow albedo due to $\mathrm{BC}$ are $0.8-4.5 \%$ with 10 ppbw $\mathrm{BC}$ and $1.9-9.5 \%$ with $30 \mathrm{ppbw}$, depending on the BC mixing state with snow and the age of the snow [Hansen and Nazarenko, 2004]. Our simulated BC concentration in Arctic snow then implies an associated decrease in snow albedo of $3.1 \pm 2.5 \%$ based on linear interpolation from the ranges above.

[26] Although our TRACE-P simulation shows that a model time constant $\tau=1 \pm 1$ days for conversion of emitted BC from hydrophobic to hydrophilic can fit the TRACE-P observational constraints on export efficiencies in Asian outflow, the crudeness of this parameterization must be acknowledged. The value of $\tau$ should vary depending on the local environment, and it is doubtful that a single time constant can properly describe the aging of $\mathrm{BC}$ and the implications for its scavenging efficiency. Further work is necessary to examine this aging and scavenging, both through observations and through improved models.

[27] Acknowledgment. This work was supported by the Atmospheric Chemistry Modeling and Analysis Program (ACMAP) of NASA.

\section{References}

Andreae, M. O., and P. Merlet (2001), Emission of trace gases and aerosols from biomass burning, Global Biogeochem. Cycles, 15(4), 955-966.

Bey, I., D. J. Jacob, R. M. Yantosca, J. A. Logan, B. Field, A. M. Fiore, Q. Li, H. Liu, L. J. Mickley, and M. Schultz (2001), Global modeling of tropospheric chemistry with assimilated meteorology: Model description and evaluation, J. Geophys. Res., 106, 23,073-23,096.

Bond, T. C., T. L. Anderson, and D. Campbell (1999), Calibration and intercomparison of filter-based measurements of visible light absorption by aerosols, Aerosol Sci. Technol., 30, 582-600.

Bond, T. C., D. G. Streets, K. F. Yarber, S. M. Nelson, J.-H. Woo, and Z. Klimont (2004), A technology-based global inventory of black and organic carbon emissions from combustion, J. Geophys. Res., 109, D14203, doi:10.1029/2003JD003697.

Carmichael, G. R., et al. (2003), Evaluating regional emission estimates using the TRACE-P observations, J. Geophys. Res., 108(D21), 8810, doi:10.1029/2002JD003116.

Chin, M., P. Ginoux, S. Kinne, O. Torres, B. Holben, B. N. Duncan, R. V. Martin, J. A. Logan, A. Higurashi, and T. Nakajima (2002), Tropospheric aerosol optical thickness from the GOCART model and comparisons with satellite and sunphotometer measurements, J. Atmos. Sci., 59, 461-483.

Chuang, C. C., J. E. Penner, J. M. Prospero, K. E. Grant, G. H. Rau, and K. Kawamoto (2002), Cloud susceptibility and the first aerosol indirect forcing: Sensitivity to black carbon and aerosol concentrations, J. Geophys. Res., 107(D21), 4564, doi:10.1029/2000JD000215.

Chung, S. H., and J. H. Seinfeld (2002), Global distribution and climate forcing of carbonaceous aerosols, J. Geophys. Res., 107(D19), 4407, doi:10.1029/2001JD001397.
Clarke, A. D., and K. J. Noone (1985), Soot in the Arctic snowpack: A cause for perturbations in radiative transfer, Atmos. Environ., 19, 2045-2053.

Clarke, A. D., et al. (2004), Size distributions and mixtures of dust and black carbon aerosol in Asian outflow: Physiochemistry and optical properties, J. Geophys. Res., 109, D15S09, doi:10.1029/ 2003JD004378.

Cooke, W. F., and J. J. N. Wilson (1996), A global black carbon aerosol model, J. Geophys. Res., 101(D14), 19,395-19,409.

Cooke, W. F., C. Liousse, H. Cachier, and J. Feichter (1999), Construction of a $1^{\circ} \times 1^{\circ}$ fossil fuel emission data set for carbonaceous aerosol and implementation and radiative impact in the ECHAM-4 model, J. Geophys. Res., 104, 22,137-22,162.

Cooper, O. R., J. L. Moody, D. D. Parrish, M. Trainer, T. B. Ryerson, J. S. Holloway, G. Hubler, and F. C. Fehsenfeld (2002), Tracer gas composition of midlatitude cyclones over the western North Atlantic Ocean: A conceptual model, J. Geophys. Res., 107(D7), 4056, doi:10.1029/ 2001JD000901.

Duncan, B. N., R. V. Martin, A. C. Staudt, R. Yevich, and J. A. Logan (2003), Interannual and seasonal variability of biomass burning emissions constrained by satellite observations, J. Geophys. Res., 108(D2), 4100, doi:10.1029/2002JD002378.

Fuelberg, H. E., C. M. Kiley, J. R. Hannan, D. J. Westberg, M. A. Avery, and R. E. Newell (2003), Meteorological conditions and transport pathways during the Transport and Chemical Evolution over the Pacific (TRACE-P) experiment, J. Geophys. Res., 108(D20), 8782, doi:10.1029/2002JD003092.

Grassian, V. H. (2001), Heterogeneous uptake and reaction of nitrogen oxides and volatile organic compounds on the surface of atmospheric particles including oxides, carbonates, soot and mineral dust: Implications for the chemical balance of the troposphere, Int. Rev. Phys. Chem., $20,467-548$

Grenfell, T. C., B. Light, and M. Sturm (2002), Spatial distribution and radiative effects of soot in the snow and sea ice during the SHEBA experiment, J. Geophys. Res., 107(C10), 8032, doi:10.1029/ 2000JC000414.

Hansen, J. E., and L. Nazarenko (2004), Soot climate forcing via snow and ice albedos, Proc. Natl. Acad. Sci. U. S. A., 101, 423-428.

Hansen, J. E., and M. Sato (2001), Trends of measured climate forcing agents, Proc. Natl. Acad. Sci. U. S. A., 98, 14,778-14,783.

Huebert, B. J., T. Bates, P. B. Russell, G. Shi, Y. J. Kim, K. Kawamura, G. Carmichael, and T. Nakajima (2003), An overview of ACE-Asia: Strategies for quantifying the relationships between Asian aerosols and their climatic impacts, J. Geophys. Res., 108(D23), 8633, doi:10.1029/ 2003JD003550.

Intergovernmental Panel on Climate Change (2001), Climate Change 2001: The Scientific Basis, Cambridge Univ. Press, New York.

Jacob, D. J., J. H. Crawford, M. M. Kleb, V. S. Connors, R. J. Bendura, J. L. Raper, G. W. Sachse, J. C. Gille, L. Emmons, and C. L. Heald (2003), Transport and Chemical Evolution over the Pacific (TRACE-P) aircraft mission: Design, execution, and first results, J. Geophys. Res., 108(D20), 9000, doi:10.1029/2002JD003276.

Jacobson, M. Z. (2001a), Strong radiative heating due to the mixing state of black carbon in atmospheric aerosols, Nature, 409, 695-697.

Jacobson, M. Z. (2001b), Global direct radiative forcing due to multicomponent anthropogenic and natural aerosols, J. Geophys. Res., 106, $1551-$ 1568 .

Jacobson, M. Z. (2003), Development of mixed-phase clouds from multiple aerosol size distributions and the effect of the clouds on aerosol removal, J. Geophys. Res., 108(D8), 4245, doi:10.1029/2002JD002691.

Jacobson, M. Z. (2004), Climate response of fossil fuel and biofuel soot, accounting for soot's feedback to snow and sea ice albedo and emissivity, J. Geophys. Res., 109, D21201, doi:10.1029/2004JD004945.

Jordan, C. E., J. E. Dibb, B. E. Anderson, and H. E. Fuelberg (2003), Uptake of nitrate and sulfate on dust aerosols during TRACE-P, J. Geophys. Res., 108(D21), 8817, doi:10.1029/2002JD003101.

Keene, W. C., A. A. P. Pszenny, J. N. Galloway, and M. E. Hawley (1986), Sea-salt corrections and interpretation of constituent ratios in marine precipitation, J. Geophys. Res., 91, 6647-6658.

Koike, M., et al. (2003), Export of anthropogenic reactive nitrogen and sulfur compounds from the east Asia region in spring, J. Geophys. Res, 108(D20), 8789, doi:10.1029/2002JD003284

Langner, J., H. Rodhe, P. J. Crutzen, and P. Zimmermann (1992), Anthropogenic influence on the distribution of tropospheric sulphate aerosol, Nature, 359, 712-716.

Li, Q. B., D. J. Jacob, R. M. Yantosca, J. W. Munger, and D. D. Parrish (2004), Export of $\mathrm{NO}_{y}$ from the North American boundary layer: Reconciling aircraft observations and global model budgets, J. Geophys. Res., 109(D2), D02109, doi:10.1029/2003JD003912.

Liousse, C., H. Cachier, and S. G. Jennings (1993), Optical and thermal measurements of black carbon aerosol content in different environments: 
Variation of the specific attenuation cross-section, sigma, Atmos. Environ. Part A, 27, 1203-1211.

Liousse, C., J. E. Penner, C. Chuang, J. J. Walton, H. Eddleman, and H. Cachier (1996), A global three-dimensional model study of carbonaceous aerosols, J. Geophys. Res., 101, 19,411-19,432.

Liu, H., D. J. Jacob, I. Bey, and R. M. Yantosca (2001), Constraints from

${ }^{210} \mathrm{~Pb}$ and ${ }^{7} \mathrm{Be}$ on wet deposition and transport in a global three-dimensional chemical tracer model driven by assimilated meteorological fields, J. Geophys. Res., 106, 12,109-12,128.

Liu, H., D. J. Jacob, I. Bey, R. M. Yantosca, B. N. Duncan, and G. W. Sachse (2003), Transport pathways for Asian pollution outflow over the Pacific: Interannual and seasonal variations, J. Geophys. Res., 108(D20), 8786, doi:10.1029/2002JD003102.

Mari, C., D. J. Jacob, and P. Bechtold (2000), Transport and scavenging of soluble gases in a deep convective cloud, J. Geophys. Res., 105, 22,255$22,267$.

Marley, N. A., J. S. Gaffney, J. C. Baird, C. A. Blazer, P. J. Drayton, and J. E. Frederick (2001), An empirical method for the determination of the complex refractive index of size-fractionated atmospheric aerosols for radiative transfer calculations, Aerosol Sci. Technol., 34, 535-549.

Mauldin, R. L., III, et al. (2003), Highlights of $\mathrm{OH}, \mathrm{H}_{2} \mathrm{SO}_{4}$, and methane sulfonic acid measurements made aboard the NASA P-3B during Transport and Chemical Evolution over the Pacific, J. Geophys. Res., 108(D20), 8796, doi:10.1029/2003JD003410.

Mauzerall, D. L., et al. (1998), Photochemistry in boimass burning plumes and implications for tropospheric ozone over the tropical South Atlantic, J. Geophys. Res., 103, 8401-8423.

Moore, K., II, et al. (2004), A comparison of similar aerosol measurements made on the NASA P3-B, DC-8, and NSF C-130 aircraft during TRACE$\mathrm{P}$ and ACE-Asia, J. Geophys. Res., 109, D15S15, doi:10.1029/ 2003JD003543.

National Research Council (2005), Radiative Forcing of Climate Change: Expanding the Concept and Addressing Uncertainties, Natl. Acad. Press, Washington, D. C.

Noone, K. J., and A. D. Clarke (1988), Soot scavenging measurements in Arctic snowfall, Atmos. Environ., 22, 2773-2778.

Ooki, A., and M. Uematsu (2005), Chemical interactions between mineral dust particles and acid gases during Asian dust events, J. Geophys. Res. 110, D03201, doi:10.1029/2004JD004737.

Palmer, P. I., D. J. Jacob, D. B. A. Jones, C. L. Heald, R. M. Yantosca, J. A Logan, G. W. Sachse, and D. G. Streets (2003), Inverting for emissions of carbon monoxide from Asia using aircraft observations over the western Pacific, J. Geophys. Res., 108(D21), 8828, doi:10.1029/2003JD003397.

Park, R. J., D. J. Jacob, M. Chin, and R. V. Martin (2003), Sources of carbonaceous aerosols over the United States and implications for natural visibility, J. Geophys. Res., 108(D12), 4355, doi:10.1029/2002JD003190.

Park, R. J., D. J. Jacob, B. D. Field, R. M. Yantosca, and M. Chin (2004), Natural and transboundary pollution influences on sulfate-nitrate-ammonium aerosols in the United States: Implications for policy, J. Geophys. Res., 109, D15204, doi:10.1029/2003JD004473.

Parungo, F., C. Nagamoto, M. Y. Zhou, A. D. A. Hansen, and J. Harris (1994), Aeolian transport of aerosol black carbon from China to the ocean, Atmos. Environ., 28, 3251-3260.

Russo, R., et al. (2003), Chemical composition of Asian continental outflow over the western Pacific: Results from Transport and Chemical Evolution over the Pacific (TRACE-P), J. Geophys. Res., 108(D20), 8804 doi:10.1029/2002JD003184

Sachse, G. W., G. F. Hill, L. O. Wade, and M. G. Perry (1987), Fastresponse, high-precision carbon monoxide sensor using a tunable diode laser absorption technique, J. Geophys. Res., 92, 2071-2081.

Stohl, A. (2001), A 1-year Lagrangian "climatology" of airstreams in the Northern Hemisphere troposphere and lowermost stratosphere, J. Geophys. Res., 106, 7263-7279.

Streets, D. G., et al. (2003), An inventory of gaseous and primary aerosol emissions in Asia in the year 2000, J. Geophys. Res., 108(D21), 8809, doi:10.1029/2002JD003093.

Thompson, A. M., K. E. Pickering, R. R. Dickerson, W. G. Ellis Jr., D. J. Jacob, J. R. Scala, W.-K. Tao, D. P. McNamara, and J. Simpson (1994), Convective transport over the central United States and its role in regional CO and ozone budgets, J. Geophys. Res., 99, 18,703-18,712.

Tu, F. H., D. C. Thornton, A. R. Bandy, M.-S. Kim, G. Carmichael, Y. Tang, L. Thornhill, and G. Sachse (2003), Dynamics and transport of sulfur dioxide over the Yellow Sea during TRACE-P, J. Geophys. Res., 108(D20), 8790, doi:10.1029/2002JD003227.

Wang, C. (2004), A modeling study on the climate impacts of black carbon aerosols, J. Geophys. Res., 109, D03106, doi:10.1029/ 2003JD004084.

Wang, Y., D. J. Jacob, and J. A. Logan (1998), Global simulation of tropospheric $\mathrm{O}_{3}-\mathrm{NO}_{x}$-hydrocarbon chemistry: 1. Model formulation, J. Geophys. Res., 103, 10,713-10,726.

Warren, S. G., and W. J. Wiscombe (1985), Dirty snow after nuclear-war, Nature, 313, 467-470.

Weber, R. J., et al. (2003), New particle formation in anthropogenic plumes advecting from Asia observed during TRACE-P, J. Geophys. Res., 108(D21), 8814, doi:10.1029/2002JD003112.

Zondlo, M. A., R. L. Mauldin, E. Kosciuch, C. A. Cantrell, and F. L. Eisele (2003), Development and characterization of an airborne-based instrument used to measure nitric acid during the NASA Transport and Chemical Evolution over the Pacific field experiment, J. Geophys. Res., 108(D20), 8793, doi:10.1029/2002JD003234

A. R. Bandy and D. C. Thornton, Department of Chemistry, Drexel University, 32nd and Chestnut Streets, Philadelphia, PA 19104, USA.

T. C. Bond, Department of Civil and Environmental Engineering, University of Illinois at Urbana-Champaign, 205 N. Mathews Avenue, Urbana, IL 61801, USA.

A. D. Clarke, School of Ocean and Earth Science and Technology, University of Hawaii at Manoa, Honolulu, HI 96822, USA.

F. L. Eisele and R. J. Weber, School of Earth and Atmospheric Sciences, Georgia Institute of Technology, Atlanta, GA 30332, USA.

D. J. Jacob, P. I. Palmer, R. J. Park, Division of Engineering and Applied Sciences, Harvard University, Cambridge, MA 02138, USA. (rpark@ fas.harvard.edu)

G. W. Sachse, NASA Langley Research Center, Mail Stop 472, 5 North Dryden Street, Hampton, VA 23681, USA.

M. A. Zondlo, National Center for Atmospheric Research, Boulder, CO 80307, USA. 


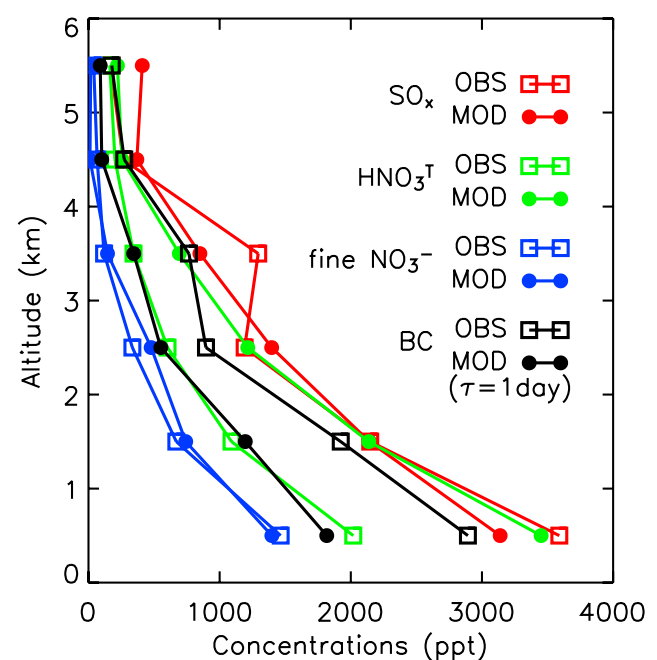

Figure 2. Mean vertical profiles of simulated (solid circles) versus observed (squares) concentrations of $\mathrm{SO}_{x}$ (red), $\mathrm{HNO}_{3}{ }^{T}$ (green), fine $\mathrm{NO}_{3}{ }^{-}$(blue), and $\mathrm{BC}$ (black) for the ensemble of TRACE-P P-3B observations over the NW Pacific $\left(30^{\circ}-41^{\circ} \mathrm{N}, 124^{\circ}-140^{\circ} \mathrm{E}\right)$. The model results were sampled along the aircraft flight tracks. The data were binned in $1-\mathrm{km}$ vertical intervals and were then averaged to construct the profiles.

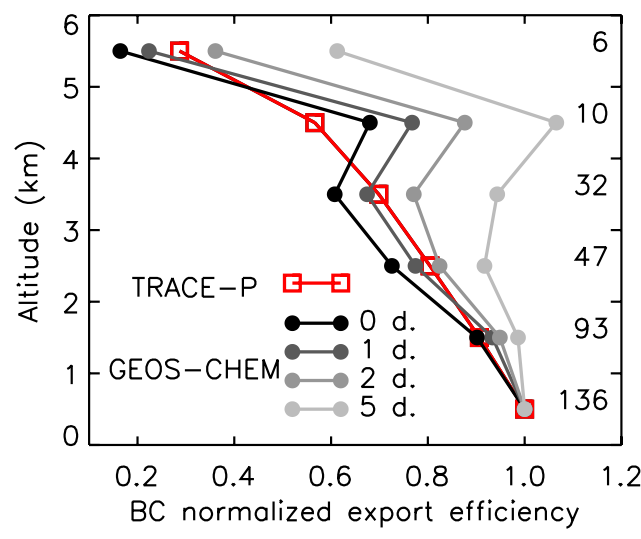

Figure 3. Comparison of simulated (solid circles) versus observed (squares) normalized export efficiencies of $\mathrm{BC}$ for the ensemble of observations and for model values of $\tau$ ranging from 0 to 5 days as indicated by the inset. The normalized export efficiencies are calculated using equation (2) for the ensemble of TRACE-P P-3B flights over the domain $\left(30^{\circ}-41^{\circ} \mathrm{N}, 124^{\circ}-150^{\circ} \mathrm{E}\right)$. The number of measurements used to calculate export efficiencies at each altitude is also shown. 